УДК 616.137.83/93-005.4-003.93]-092.9

DOI 10.11603/bmbr.2706-6290.2019.1.10519

А. Т. Телев’як, П. Р. Сельський, О. М. Герман, М. В. Ющак, Б. П. Сельський

Тернопільський національний медичний університет імені I. Я. Горбачевського МОЗ України

\title{
СТРУКТУРНО-ПРОСТОРОВЕ РЕМОДЕЛЮВАННЯ СУДИННОГО РУСЛА ЗАДНІХ КІНЦІВОК ЩУРІВ ПРИ ГОСТРІЙ ІШЕМІЇ
}

\section{Структурно-просторове ремоделювання судинного русла задніх кінцівок щурів при гострій ішемії}

А. Т. Телев'як, П. Р. Сельський, О. М. Герман, М. В. Ющак, Б. П. Сельський

Тернопільський національний медичний університет імені І. Я. Горбачевського мОЗ України

Резюме. Артеріальні турнікети широко застосовують у клінічній практиці при ангіо- та артропластиках, а при пораненнях кінцівки їх використання нерідко відбувається за життєвими показаннями. Після зняття турнікета і відновлення кровопостачання кінцівки виникає багатофракторне ураження ішемізованих та віддалених від місця ішемії тканин, яке отримало назву ішемічно-реперфрузійного синдрому. Проте структурно-просторова перебудова артеріального русла кінцівок при розвитку даного синдрому залишається маловивченою.

Мета дослідження - встановити особливості структурно-просторового ремоделювання артерій задніх кіниівок шурів при гострій ішемії, спричиненій накладанням артеріального джгута, та наступній реперфузії.

Матеріали і методи. Проведено рентгенангіографрічне та морфометричне дослідження артеріальних судин задніх кінцівок 30 щурів за умов експериментальної гострої ішемії. У контрольній групі було 6 інтактних тварин. Гостру ішемію спричиняли шляхом накладання гумових джгутів SWAT шириною 5-6 мм на задні кінцівки тварин, на рівні пахвинної складки протягом 2 год під тіопенталовим знеболюванням, а реперфрузію моделювали шляхом зняття турнікета.

Просторову організацію артерій вивчали у судинних розгалуженнях (трійниках): у стегновій ділянці - в місці роздвоєння м'язової гілки, у підколінній ділянці - в місці бісруркації м'язової краніальної гілки, а в гомілковій - у місці поділу підколінної артерії на краніальну та каудальну великогомілкові артерії. У судинному трійнику вимірювали діаметри основного стовбура, товстішої і тоншої артеріальних гілок, сумарний кут галуження артерій та його складові частини - кут відхилення товстішої і тоншої гілок.

Результати. Результати морфометричних досліджень встановили структурно-просторове ремоделювання артеріального русла задніх кінцівок щурів у стегновій, підколінній та гомілковій ділянках кінцівки нижче місця накладання артеріального турнікета. В артеріальних трійниках вказаних ділянок кінцівки виявлено збільшення пересічного діаметра основних стовбурів артерій, яке досягало максимуму через 1 добу
Structural-spatial remodeling of vascular bed of hind limbs in rats at acute ischemia

A. T. Televiak, P. R. Selskyy, O. M. Herman, M. V. Yushchak, B. P. Selskyy

I. Horbachevsky Ternopil National Medical University

e-mail: totel@ukr.net

Summary. Arterial tourniquets are widely used in clinical practice for angio- and arthroplasty, and by the injury of the limbs their use is often occurring according to vital indications. A multifactorial lesion of tissues both ischemic and distant from the site of ischemia, known as the ischemia-reperfusion syndrome arises after removing the tourniquet and blood supply restoration to the limb. However, the structural-spatial restructuring of the arterial bed of the extremities by the development of this syndrome remains little studied.

The aim of the study - to establish the peculiarities of structural-spatial remodeling the arteries of the rat's hind limbs by acute ischemia, caused by the application of an arterial tourniquet.

Materials and Methods. The X-ray angiography and morphometric study of the arterial vessels of the hind limbs of 30 rats under condition of experimental acute ischemia was performed. There were 6 intact animals in the control group. Acute ischemia was caused by application of SWAT rubber bands on the hind limbs of animals, 5-6 $\mathrm{mm}$ in width, at the inguinal fold level within 2 hours under thiopental anesthesia. A reperfusion was modeled by removing the tourniquet.

The spatial organization of the arteries was studied in vascular branchings (tees): in the femoral area - at the place of the bifurcation of the muscular branch, in the popliteal area - at the site of bifurcation of the muscular cranial branch, and at the tibial area - at the site of the division of the popliteal artery on the cranial and caudal tibial arteries. In vascular tee the diameter of main trunk, the diameters of thicker and thinner arterial branch, the total angle of arterial branching and its components - the angle of deflection of thicker and thinner branch were measured.

Results. Results of morphometric studies have established structural-spatial remodeling of the arterial bed of hind limbs of rats in the femoral, popliteal and tibial areas of the limb below the site of arterial tourniquet overlay. In the arterial tees of these areas of the limb an increase of average diameter of the main trunks of the arteries, which reached a maximum after 1 day of the experiment, was revealed. Thus, a maximum increase of diameter of the main trunk

(C)А. Т. Телев'як та ін., 2019

ISSN 2706-6282(print)

ISSN 2706-6290(online)
Вісник медичних і біологічних досліджень

Bulletin of Medical and Biological Research 
експерименту. Так, максимальне зростання діаметра основного стовбура трійника в стегновій ділянці становило 13,11 \%, у підколінній ділянці - 13,95 \%, а в гомілковій - 14,99\% (для всіх р<0,05) порівняно з групою контролю. При цьому збільшувався діаметр як товстішої, так і (більшою мірою) тоншої трійникової гілки. Одночасно виявлено збільшення загального кута галуження дочірніх гілок в стегновій ділянці на 9,02 \%, в підколінній ділянці - на 8,89\%, а у гомілковій - на 6,36 \% порівняно з групою контролю (для всіх р<0,05), більшою мірою унаслідок збільшення відхилення тоншої гілки. Через 14 діб реперфузії морфометричні показники повертались до рівня значень контрольної групи.

Висновки. Результати рентгенангіографічного та морфометричного досліджень підтверджують ремоделювання артерій задніх кінцівок щурів у результаті розвитку в дослідних тварин ішемічно-реперфузійного синдрому, яке проявлялося збільшенням пересічного діаметра основних стовбурів артерій судинних трійників та збільшенням кута галуження дочірніх гілок. При цьому виявлено збільшенням діаметрів і кутів відхилення як товстішої, так і (більшою мірою) тоншої трійникової гілки.

Ключові слова: гостра ішемія; реперфузія; артерія; судинний трійник; рентгенангіограсрія; ремоделювання.

\section{ВСТУП}

Артеріальні турнікети широко застосовують у клінічній практиці при ангіо- та артропластиках, а в бойових умовах при пораненнях кінцівки їх використання нерідко відбувається за життєвими показаннями [1-3]. Після зняття турнікета і відновлення кровопостачання кінцівки виникає багатосракторне ураження ішемізованих та віддалених від місця ішемії тканин, яке отримало назву ішемічно-реперорузійного синдрому $[4,5]$

Вивченню структурних змін гемомікроциркуляторного русла та м'яких тканин кінцівок при розвитку даного синдрому присвячено низку досліджень $[6,7]$, проте структурно-просторове ремоделювання артеріального русла кінцівок при розвитку ішемії-реперфузії залишається маловивченим.

Метою дослідження було встановити особливості структурно-просторового ремоделювання артерій задніх кінцівок щурів при гострій компресійній ішемії, спричиненій накладанням артеріального турнікета, та наступній реперорузії.

\section{МАТЕРІАЛИ I МЕТОДИ}

Проведено рентгенангіографрічне та морфометричне дослідження артерій 30 щурів за умов експериментальної гострої ішемії-реперфузії. У контрольній групі було 6 інтактних тварин.

Дослідження проведено з дотриманням основних положень Правил проведення робіт з використанням експериментальних тварин, затверджених Указом МО3 України № 753 від 12.08.1997 р., of the tee in the femoral area was $13.11 \%$, in the popliteal area $-13.95 \%$, and in the tibial - $14.99 \%$ (for all groups $p<0.05)$ in comparison with the control group. Herewith, the diameter of both thicker and (to a greater extent) thinner tee branch increased. Simultaneously an increase of the total branching angle of subsidiary branches in the femoral area by $9.02 \%$, in the popliteal area - by $8.89 \%$, and in the tibial area - by $6.36 \%$ in comparison with the control group (for all $p<0.05$ ) was found, which was to a greater extent due to the increasing in the deviation of the thinner branch. After 14 days of reperfusion, the morphometric indices returned to the control group level.

Conclusions. The results of $X$-ray examination and morphometric study confirm the remodeling of the arteries of the rats hind limbs as a result of the development of ischemia-reperfusion syndrome in experimental animals, which was manifested in increasing of the average diameter of the main trunks of the arteries of the vascular tees and in increasing of the branching angle of the both subsidiary branches. Herewith, an increase of the diameters and deflection angles of both thicker and (to a greater extent) thinner tee branch was revealed.

Key words: acute ischemia; reperfusion; artery; vascular tee; X-ray angiography; remodeling.

Конвенції Ради Європи про охорону хребетних тварин, які використовуються в експериментах та інших наукових цілях (1986), Указу МОЗ України № 281 від 01.11.2000 р. «Про заходи з подальшого вдосконалення організаційних норм роботи з використанням експериментальних тварин» та Закону України № 3447- IV «Про захист тварин від жорстокого поводження» (2006).

Гостру ішемію викликали шляхом накладання гумових джгутів SWAT шириною 5-6 мм на задні кінцівки тварин на рівні пахвинної складки під тіопентал-натрієвим знеболюванням. Реперфузійний синдром моделювали шляхом зняття турнікета через 2 год після його накладання.

Під час експерименту тварин поділили на 5 груп дослідження. Модель раннього постішемічного періоду було представлено групами тварин із реперфузійними змінами через 1 год, 2 год та 1 добу після зняття турнікета, а модель пізнього періоду - групами тварин 3 реперсузією через 7 та 14 діб (по 6 щурів у кожній). Евтаназію тварин здійснювали шляхом декапітації під тіопентал-натрієвим знеболюванням.

Просторову організацію артеріального кровоносного русла задніх кінцівок вивчали за допомогою контрастної рентгенангіографрії. У грудну частину аорти за допомогою 20 мл шприца через катетер вводили 5 \% розчин аміаку для промивання судинного русла, після чого протягом 15-20 хв до відчуття опору поршня вводили рентгенконтрастну речовину (підігріта водна суспензія дрібнодисперсного свинцевого сурика). Отримані 
препарати промивали під проточною водою та фротографували в передньо-задній проекції за допомогою цифрового рентгенівського апарата.

Просторову організацію судинного русла задніх кінцівок щурів вивчали, використовуючи методику, описану І. Є. Герасимюком та співавт. [8]. Вимірювання стереометричних параметрів судинних трійників у стегновій і підколінній ділянках проводили в місці роздвоєння м'язово- та м'язової краніальної артерій (найбільших артеріальних гілок вказаних ділянок), а у гомілковій ділянці - в місці поділу підколінної артерії на краніальну та каудальну великогомілкові артерії.

У судинному трійнику здійснювали вимірювання діаметра основного стовбура (Д $)$, товстішої (Д $)$ і тоншої $\left(Д_{2}\right)$ гілок, сумарний кут галуження артерій $\left(\varphi_{0}\right)$ та його складові частини: кут відхилення товстішої $\left(\varphi_{1}\right)$ і тоншої $\left(\varphi_{2}\right)$ гілок. На підставі вимірюваних характеристик трійника розраховували коефріцієнт асиметрії $\left(\mathrm{H}_{2}\right)$ за фрормулою: $\mathrm{H}_{2}=Д_{2}^{2}$ / $\left(Д_{1}^{2}+Д_{2}^{2}\right)$.

Вимірювання діаметра артерій у трійнику біля їх усть та кутів галужень проводили за допомогою за допомогою програмного забезпечення для обробки й аналізу зображень SEO Image Lab фрірми «Sumy Electron Optics».

Статистичну обробку матеріалу проводили 3 використанням пакета програм «Microsoft Excel» (Microsoft Office 2007). Визначали такі показники: середнє арифметичне (М), середнє квадратичне відхилення (б) і помилку середнього арифметичного (m). Використовували методи непараметричної статистики. При цьому статистичну значущість показників визначали за U-критерієм Манна-Уїтні.

\section{РЕЗУЛЬТАТИ ТА ОБГОВОРЕННЯ}

За допомогою рентгенконтрастного ангіографрічного дослідження виявлено структурно-просторове ремоделювання артеріального русла задніх кінцівок щурів у стегновій, підколінній та гомілковій ділянках нижче місця накладання артеріального турнікета. При візуальному аналізі рентгенангіограм у тварин раннього реперфузійного періоду відмічали незначне розширення великих артерій задньої кінцівки, яке досягало максимуму через 2 год і 1 добу реперфузії, та помірне збіднення судинного рисунка в периферійних ділянках артеріального русла порівняно з групою інтактних щурів (рис. ).

При морфометрії у вказаних ділянках кінцівки виявлено збільшення пересічного діаметра основних стовбурів артерій, що утворюють судинні трійники, яке виникало вже через 1 год реперфузії і досягало максимуму через 1 добу експерименту (табл. 1).

Так, значуще максимальне зростання діаметра основного стовбура артеріального трійника в стег- новій ділянці становило 13,11 \%, у підколінній ділянці - 13,95 \%, а у гомілковій - 14,99\% (для всіх p<0,05) порівняно з групою контролю. При цьому діаметр товстішої гілки збільшувався на 9,08 \% $(p<0,05), 12,75 \%(p<0,05)$ та 8,35\% $\%(p>0,05)$ у стегновій, підколінній та гомілковій ділянках кінцівки відповідно. Більш вираженим було збільшення пересічного діаметра тоншої артеріальної гілки - на $17,89 \%(p<0,005)$ у стегновій ділянці, на 17,70\% $(p<0,05)$ - у підколінній та на 17,88 \% (p>0,05) у гомілковій ділянці кінцівки. При цьому виявлено значуще зростання коефіцієнта асиметрії в судинних трійниках у стегновій ділянці на 10,90 \%, у підколінній - на 7,70 \%, а в гомілковій - на 8,15\% (для всіх $p<0,05)$. Зростання даного коефіцієнта свідчить про збільшення діаметра дочірніх гілок у судинних трійниках більшою мірою за рахунок тоншої гілки.

Збільшення кута галуження артеріальних гілок судинного трійника (табл. 2) досягло максимального значення у тварин із реперфузією через 1 добу і було в цій групі статистично значущими для $\varphi_{0}$ та $\varphi_{2}$. Зокрема, загальний кут галуження дочірніх гілок збільшувався в стегновій ділянці на 9,02 \%, у підколінній - на 8,89 \%, а у гомілковій - на 6,36 \% (для всіх $p<0,05)$ порівняно 3 групою контролю. Збільшення кута галуження дочірніх артерій більшою мірою зумовлено збільшенням відхилення тоншої гілки, для якої зростання $\varphi_{2}$ було статистично достовірне в усіх ділянках кінцівки через 2 год реперфузії: в ділянці стегна - на 14,18 \%, в підколінній ділянці - на 9,52 \%, а в гомілковій склало 10,74 \% порівняно 3 контрольною групою тварин (для всіх $\mathrm{p}<0,05)$.

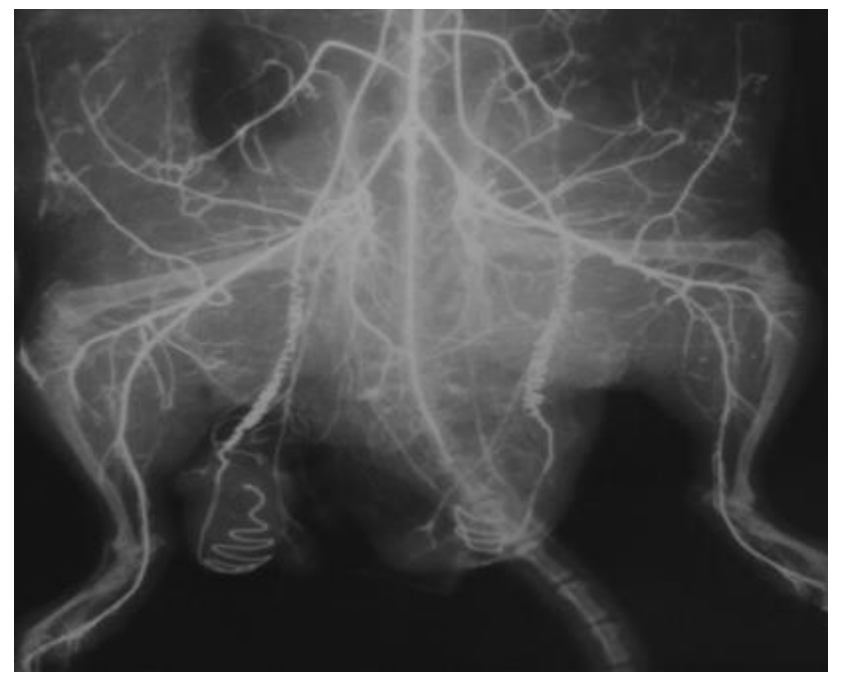

Рис. Артеріальне русло задніх кінцівок щура через 2 год модельованої ішемії-реперфузії. Розширення магістральних артерій та збіднення судинного рисунка в перисрерійних ділянках у правій ішемізованій кінцівці. Фотограсрія контрастної рентгенангіограми. 
Таблиця 1. Показники діаметра основного стовбура (Д $)$, товстішої (Д $)$ та тоншої (Д $)$ гілок судинного трійника, коесріцієнта асиметрії $\left(\mathrm{H}_{2}\right)$ у різні періоди ішемії-реперфруіії $(\mathrm{M} \pm \mathrm{m})$

\begin{tabular}{|c|c|c|c|c|c|}
\hline \multirow{2}{*}{ Ділянка кінцівки } & \multirow{2}{*}{ Реперфузія, через } & \multicolumn{4}{|c|}{ Параметри } \\
\hline & & $Д_{0}, \mathrm{MM}$ & $Д_{1}, \mathrm{~mm}$ & $Д_{2}$, мм & $\mathrm{H}_{2}$ \\
\hline \multirow[t]{6}{*}{ Стегнова } & Контроль & $0,72 \pm 0,02$ & $0,62 \pm 0,02$ & $0,44 \pm 0,02$ & $33,30 \pm 0,98$ \\
\hline & 1 год & $0,78 \pm 0,04$ & $0,68 \pm 0,05$ & $0,49 \pm 0,03$ & $35,33 \pm 2,58$ \\
\hline & 2 год & $0,81 \pm 0,03^{*}$ & $0,66 \pm 0,03$ & $0,51 \pm 0,03^{*}$ & $36,79 \pm 1,53$ \\
\hline & 1 добу & $0,81 \pm 0,02^{*}$ & $0,67 \pm 0,01^{\text {** }}$ & $0,52 \pm 0,01^{* *}$ & $36,93 \pm 1,07^{*}$ \\
\hline & 7 діб & $0,74 \pm 0,03$ & $0,64 \pm 0,03$ & $0,48 \pm 0,03$ & $35,69 \pm 1,73$ \\
\hline & 14 діб & $0,72 \pm 0,02$ & $0,62 \pm 0,02$ & $0,45 \pm 0,02$ & $34,24 \pm 1,58$ \\
\hline \multirow[t]{6}{*}{ Підколінна } & Контроль & $0,45 \pm 0,01$ & $0,39 \pm 0,01$ & $0,27 \pm 0,01$ & $33,22 \pm 0,48$ \\
\hline & 1 год & $0,49 \pm 0,02$ & $0,42 \pm 0,02$ & $0,30 \pm 0,01$ & $34,18 \pm 1,36$ \\
\hline & 2 год & $0,51 \pm 0,03^{*}$ & $0,44 \pm 0,01^{*}$ & $0,32 \pm 0,03$ & $33,94 \pm 2,65$ \\
\hline & 1 добу & $0,50 \pm 0,02^{*}$ & $0,43 \pm 0,02$ & $0,32 \pm 0,02^{*}$ & $35,78 \pm 0,76^{*}$ \\
\hline & 7 діб & $0,46 \pm 0,02$ & $0,39 \pm 0,03$ & $0,29 \pm 0,02$ & $34,93 \pm 1,87$ \\
\hline & 14 діб & $0,46 \pm 0,03$ & $0,38 \pm 0,02$ & $0,28 \pm 0,01$ & $34,93 \pm 1,42$ \\
\hline \multirow[t]{6}{*}{ Гомілкова } & Контроль & $0,68 \pm 0,02$ & $0,46 \pm 0,02$ & $0,39 \pm 0,01$ & $42,11 \pm 1,20$ \\
\hline & 1 год & $0,75 \pm 0,04$ & $0,49 \pm 0,03$ & $0,42 \pm 0,03$ & $43,17 \pm 0,98$ \\
\hline & 2 год & $0,79 \pm 0,05^{*}$ & $0,50 \pm 0,03$ & $0,46 \pm 0,03$ & $45,55 \pm 0,81^{*}$ \\
\hline & 1 добу & $0,77 \pm 0,04^{*}$ & $0,50 \pm 0,03$ & $0,44 \pm 0,04$ & $43,76 \pm 1,02$ \\
\hline & 7 діб & $0,71 \pm 0,02$ & $0,47 \pm 0,03$ & $0,40 \pm 0,04$ & $42,38 \pm 0,64$ \\
\hline & 14 діб & $0,68 \pm 0,03$ & $0,46 \pm 0,03$ & $0,38 \pm 0,02$ & $41,44 \pm 1,34$ \\
\hline
\end{tabular}

Примітка. * - p<0,05; ${ }^{* *}-p<0,005$.

Таблиця 2. Показники сумарного кута галуження $\left(\varphi_{0}\right)$ та кута відхилення товстішої $\left(\varphi_{1}\right)$ і тоншої $\left(\varphi_{2}\right)$ артеріальних гілок у судинному трійнику в різні періоди ішемії-реперфрузії (M $\pm m)$

\begin{tabular}{|c|c|c|c|c|}
\hline \multirow{2}{*}{ Ділянка кінцівки } & \multirow{2}{*}{ Реперфузія, через } & \multicolumn{3}{|c|}{ Значення кута, град. } \\
\hline & & $\varphi_{0}$ & $\varphi_{1}$ & $\varphi_{2}$ \\
\hline \multirow[t]{6}{*}{ Стегнова } & Контроль & $42,50 \pm 1,06$ & $20,17 \pm 0,87$ & $22,33 \pm 0,84$ \\
\hline & 1 год & $45,33 \pm 1,89$ & $20,33 \pm 0,88$ & $25,00 \pm 1,63$ \\
\hline & 2 год & $46,17 \pm 1,89$ & $20,67 \pm 1,80$ & $25,50 \pm 0,43^{*}$ \\
\hline & 1 добу & $46,33 \pm 1,52^{*}$ & $20,67 \pm 0,95$ & $25,67 \pm 0,84^{*}$ \\
\hline & 7 діб & $44,50 \pm 1,45$ & $20,17 \pm 0,67$ & $24,33 \pm 0,95$ \\
\hline & 14 діб & $43,33 \pm 1,69$ & $20,00 \pm 1,81$ & $23,33 \pm 1,12$ \\
\hline \multirow[t]{6}{*}{ Підколінна } & Контроль & $45,00 \pm 1,46$ & $20,50 \pm 0,76$ & $24,50 \pm 1,06$ \\
\hline & 1 год & $47,83 \pm 2,04$ & $21,16 \pm 1,08$ & $26,67 \pm 2,01$ \\
\hline & 2 год & $48,33 \pm 1,50^{*}$ & $21,50 \pm 1,34$ & $26,83 \pm 0,79^{*}$ \\
\hline & 1 добу & $49,00 \pm 1,15^{*}$ & $21,83 \pm 0,79$ & $27,17 \pm 1,08$ \\
\hline & 7 діб & $46,17 \pm 2,10$ & $20,67 \pm 0,79$ & $25,50 \pm 0,95$ \\
\hline & 14 діб & $45,50 \pm 2,13$ & $20,17 \pm 1,63$ & $25,33 \pm 1,12$ \\
\hline \multirow[t]{6}{*}{ Гомілкова } & Контроль & $47,17 \pm 1,78$ & $22,33 \pm 0,95$ & $24,83 \pm 1,11$ \\
\hline & 1 год & $49,83 \pm 1,54$ & $22,67 \pm 1,31$ & $27,17 \pm 1,28$ \\
\hline & 2 год & $50,17 \pm 1,68^{*}$ & $22,67 \pm 1,02$ & $27,50 \pm 1,75^{*}$ \\
\hline & 1 добу & $49,83 \pm 1,25^{*}$ & $23,17 \pm 0,79$ & $26,67 \pm 1,69$ \\
\hline & 7 діб & $48,00 \pm 2,22$ & $22,33 \pm 0,95$ & $25,67 \pm 2,17$ \\
\hline & 14 діб & $47,67 \pm 2,26$ & $22,33 \pm 0,95$ & $25,33 \pm 1,38$ \\
\hline
\end{tabular}

Примітка. ${ }^{*}-\mathrm{p}<0,05$.

У тварин групи пізнього реперфузійного періоду виявлено поступове повернення усіх досліджуваних морфометричних показників до рівня групи контролю.

ВИснОВкИ. 1. Зміни стереометричних параметрів у судинних трійниках виявлялися збільшен- ням діаметра основного стовбура та обох дочірніх гілок, а також загального кута галуження і кутів відхилення обох гілок. Діаметр і кут відхилення дочірніх гілок більшою мірою зростав за рахунок тоншої гілки, що підтверджується значущим зростанням коефріцієнта асиметрії. 
2. Виявлені зміни виникали вже через 1 год реперфузії і досягали максимального вираження через 2 год та 1 добу після зняття турнікета.

3. Виявлені особливості структурно-просторового ремоделювання великих артерій кінцівки щурів свідчать про їх збільшене кровонаповнення та компенсаторне розширення у ранньому періоді ішемічно-реперфузійного ураження, що виникає унаслідок зменшення перфузії у артеріях малого калібру та судинах гемомікроциркуляторного русла.

4. У тварин пізнього реперфузійного періоду стереометричні параметри ремоделювання арте-

\section{СПИСОК ЛІТЕРАТУРИ}

1. New tourniquet device concepts for battlefield hemorrhage control / J. F. Kragh, C. Murphy, M. A. Dubicket [et al.] // Army Med. Dept. J. - 2011. - P. 38-48.

2. Kumar K. Tourniquet application during anesthesia: "What we need to know?" / K. Kumar, C. Railton, Q. Tawfic // Journal of Anaesthesiology Clinical Pharmacology. - 2016. - Vol. 32, No. 4. - P. 424-430.

3. Use of a tourniquet in total knee arthroplasty: a systematic review and meta-analysis of randomized controlled trials / F. Jiang, H. Zhong, Y. Hong, G. Zhao // J. Orthop. Scien. - 2015. - Vol. 20, No. 1. - P. 110-123.

4. Геник С. М. Реперфузійний синдром після реваскуляризації ішемії нижніх кінцівок / С. М. Геник, А. В. Симчич // Серце і судини. - 2016. - № 3. - С. 104-108.

5. Кутепов Д. Е. Патогенез синдрома ишемии-реперфрузии / Д. Е. Кутепов, М. С. Жигалова, И. Н. Пасечник.

\section{REFERENCES}

1. Kragh JF, Murphy C, Dubick MA, Baer DG, Johnson J, Blackbourne LH. New tourniquet device concepts for battlefield hemorrhage control. US Army Med Dept J. 2011: 38-48.

2. Kumar K, Railton C, Tawfic Q. Tourniquet application during anesthesia: What we need to know? J Anaesthesiol Clin Pharmacol. 2016;32(4): 424-30. doi: 10.4103/09709185.168174

3. Jiang FZ, Zhong HM, Hong YC, Zhao GF. Use of a tourniquet in total knee arthroplasty: a systematic review and meta-analysis of randomized controlled trials J Orthop Sci. 2015;20(1): 110-23. doi: 10.1007/s00776-014-0664-6.

4. Henyk SM, Symchych AV. [Reperfusion syndrome after lower limb ischemia revascularization]. Sertse i Sudyny. 2016;3: 104-8. Ukrainian. рій зменшувались через 7 діб реперфузії, а через 14 діб вони повертались до рівня показників інтактної групи тварин.

\section{ПЕРСПЕКТИВИ ПОДАЛЬШИХ ДОСЛІДЖЕНЬ}

Отримані результати можуть слугувати основою для подальших досліджень ремоделювання судинного русла кінцівок при різних видах компресійної травми, її поєднанні з іншими патологічними станами (крововтрата різного ступеня, краніоскелетна травма, опіки, дегідратація тощо), та корекції перфузійних порушень фрармакологічними засобами.

Казанский медицинский журнал // 2018. - № 99 (4). C. 640-644.

6. Tennant D. The role of HIFs in ischemia-reperfusion injury / D. Tennant, N. J. Howell // Hypoxia. - 2014. Vol. 2. - P. 107-111.

7. Молекулярные механизмы развития и адресная терапия синдрома ишемии-реперфузии / О. А. Гребенчиков, В. В. Дихванцев, Е. Ю. Плотников [и др.] // Актуальные вопросы анестезиологии и реаниматологии. - 2014. - № 3. - С. 59-67.

8. Герасимюк І. Є. Особливості морфоорункціональної перебудови кровоносних судин яєчка щурів після дозованої компресії сім'яного канатика / І. Є. Герасимюк, Т. Я. Стравський, А. В. Гантімуров // Вісник проблем біології та медицини. - 2015. - Т. 4, № 2. C. 241-246.

5. Kutepov DE, Zhigalova MS, Pasechnik IN. [Pathogenesis of ischemia-reperfusion syndrome]. Kazanskiy med zhurn. 2018;99(4): 640-4. Russian. doi: 10.17816/KMJ2018-640

6. Tennant D, Howell NJ. The role of HIFs in ischemiareperfusion injury. Hypoxia. 2014;2: 107-11. doi: 10.2147/ HP.S49720

7. Grebenchikov OA, Likhvantsev VV, Plotnikov EYu, Silachov DN, Pevzner IB, Zorova LD, et al. [Molecular mechanisms of development and targeted therapy of ischemia-reperfusion syndrome]. Aktual vopr anest i reanimatol. 2014;3: 59-67. Russian.

8. Herasymiuk IYe, Stravskyi TYa, Hantimurov AV. [Features of morphofunctional reconstruction of blood vessels of rat testes after dosed compression of the familial cord]. Visnyk problem biol ta med. 2015;2: 241-46. Ukrainian.

Отримано 02.09.19 